\title{
Os outros da festa: um sobrevoo por festivais yawanawa e huni kuin
}

The others of the party: a flight over Yawanawa and Huni Kuin festivals

\author{
Aline Ferreira Oliveira ${ }^{*}$ \\ *Universidade de São Paulo - São Paulo, SP, Brasil \\ Doutoranda em Antropologia Social (bolsista Capes) \\ aliferreiraoliveira@gmail.com
}




\title{
Resumo
}

Este artigo reflete sobre relações dos Yawanawa e dos Huni Kuin, povos de língua pano residentes no Acre, com os nawa ("brancos"), especialmente com religiões ayahuasqueiras e movimentos (neo)xamânicos. Atualmente, algumas aldeias yawanawa e huni kuin vêm promovendo festivais, como um modo de apresentar a cultura. Como bons anfitriões, recebem com beleza e entusiasmo os nawa ("brancos") para fazer festa e sentir a força da floresta. Analisaremos como certos modos expressivos emergem destes encontros e sobre o que são capazes de produzir em termos de novos arranjos. Consideraremos a centralidade das festas e da ayahuasca em processos inventivos da cultura, evidenciando traduções de mundos diversos, por meio de fluxos multidirecionais de entendimentos, categorias e práticas festivas e xamânicas. Acompanharemos os caminhos de usos e transformações do chá, aqui designado pelo nome local "cipó" - em suas multiplicidades ontológicas enquanto daime, uni ou nixi pae - a partir da diversidade de relações que indígenas yawanawa e huni kuin estabelecem com religiões ayahuasqueiras, especialmente com o Santo Daime.

Palavras-chave: festa; (neo)xamanismo; Pano; Santo Daime.

\begin{abstract}
This article reflects on some of the relationships of the Yawanawa and the Huni peoples, who speak Pano language and are residents of the State of Acre, Brazil, with the nawa ("white people"), especially those who participate in ayahuasca religions and neo-shamanic movements. Currently, a number of Yawanawa and Huni Kuen indigenous settlements have been promoting festivals as a way of presenting cultures. They enthusiastically receive the nawa ("people", "other people", "foreigners") to party and feel the strength of the forest. We will analyze how certain ways of expression emerge from these encounters and what they are capable of producing in terms of new arrangements. We will consider the centrality of the parties and ayahuasca in processes of invention of culture, evidencing translations of diverse worlds, through multidirectional flows of understandings, categories, festive and shamanic practices which take place at these encounters. We will observe ways of uses and transformations of the tea, here denominated ayahuasca, daime, uni or nixi pae, from the diversity of relations that indigenous Yawanawa and Huni Kuen establish with ayahuasca religions, especially with Santo Daime.
\end{abstract}

Keywords: party; (neo) shamanism; Pano; Santo Daime. 
Atualmente, os Yawanawa ${ }^{1}$ e os Huni Kuin ${ }^{2}$ estão construindo novas formas de relações com os nawa ("brancos"), através de modos diversos de produzir "cultura", especialmente por meio de rituais de ayahuasca e de suas festas. Neste artigo $^{3}$ iremos refletir sobre como os fluxos de pessoas, "medicinas" ${ }^{4} \mathrm{e}$ formas expressivas transformam os modos de ação ritual do uni (yawanawa) e nixi pae (huni kuin). Para isto, damos especial atenção ao fenômeno recente no Acre em torno dos chamados "festivais", enquanto um tipo de evento próprio para receber visitantes, ao modo do que é conhecido localmente como mariri. ${ }^{5}$

Como indicado pela literatura sobre festas ameríndias, sabemos que elas são momentos privilegiados de relação com a alteridade. O mariri yawanawa é "instrumento de atração" (Carid Naveira, 1999, p. 101) que atua como um dispositivo para receber aqueles que vêm de fora, sejam nawa ou parentes yawanawa que moram fora da Terra Indígena. Em uma festa de caxiri ${ }^{6}$ entre os Wajãpi,

1 Os Yawanawa são o "povo da queixada" (em que yawa significa "queixada" e nawa é um marcador de alteridade, geralmente traduzido por "povo" ou "outro povo") e totalizam aproximadamente 1000 pessoas que residem em diversas aldeias na Terra Indígena do Rio Gregório, às margens de rio homônimo, situado no município de Tarauacá (AC).

2 Os Huni Kuin ("gente verdadeira") falantes de hatxa kuin, constituem a mais numerosa população indígena do Acre, totalizando atualmente cerca de 10.000 pessoas, habitam em distintas unidades de Terra Indígena, em variados rios: Jordão, Tarauacá, Humaitá, Envira, Purus, igarapé do Caucho.

3 Uma versão prévia deste artigo foi apresentada sob o título "Festivais Pano: rituais, festas e tradução" no V Encontro dos Alunos, que ocorreu entre os dias 8 a 11 de setembro de 2015 no Museu Nacional (UFRJ/MN), e debatida por Tiago Coutinho e Lucas Krastup, a quem sou grata pelos comentários e sugestões. Agradeço a Brisa Totti pela revisão do artigo, a Oscar Sáez por comentários gerais, e a Marta Amoroso pela menção ao meu projeto de doutorado enquanto "os outros da festa". A presente análise baseia-se em pesquisas de campo na graduação (Ferreira Oliveira, 2009) e mestrado (Ferreira Oliveira, 2012) em rituais nas cidades, conjuntamente com a pesquisa de doutorado em curso, e a participação nos seguintes festivais: I e II Festival Xina Bena dos Huni Kuin no Rio Jordão, realizados no rio Tarauacá nos anos de 2010 e 2011; II Festival Internacional Huni Kuin do Caucho nas proximidades de Tarauacá (em 2016); Festival Noke Koi 2016; Festival Yawa 2011 e Mariri Yawanawa 2012 e 2016; e Festival Nixpu Pima no Rio Tarauacá (em 2017).

4 Aqui referimo-nos à ayahuasca, rapé e outras "medicinas da floresta", conforme veremos mais adiante.

5 Segundo Carid Naveira (1999, p. 100), o termo mariri é um neologismo kulina, que segundo os Yawanawa teria sido importado através dos Katukina. Silva (1997, p. 32 apud Carid Naveira, 1999, p. 101) parte da premissa que mariri tampouco é uma palavra originalmente kulina "sendo utilizada para tratar de atividades também não originárias dos Kulina".

6 Caxiri é uma bebida fermentada de mandioca que produz embriaguez. Podemos considerá-la como análoga à caiçuma consumida em festas por grupos indígenas no Acre. 
tudo conduz à alteridade, pois reúne grupos diferentes, e opera com cantos roubados (ou fornecidos) por agentes não humanos ou inimigos de guerra: e isso deve ser celebrado (Sztutman, 2003, p. 32-33). Ainda no mesmo sentido, Perrone-Moisés (2015) afirma que "as festas ameríndias por definição, não são feitas em família nem entre amigos": justamente tratam de receber visitantes forasteiros, advindos de outras aldeias e outros mundos. Apontando no mesmo sentido, Calavia Sáez e Arisi (2013, p. 205, tradução minha) argumentam que rituais feitos para o público ou para turistas (longe de serem inautênticos) ocupam um lugar central nas ações rituais amazônicas, inclusive em suas versões mais comerciais, justamente por operarem "um padrão tradicional de captura e absorção de elementos externos".

Dito isso, considerando que o grande atrativo desses festivais é justamente sua dimensão xamânica - mas podemos considerar a performatividade da beleza e da alegria como o distintivo desses eventos - é necessário refletirmos sobre alguns contrastes e cruzamentos acerca de temas caros à etnologia ameríndia, em especial a festa e o xamanismo. Mas, para isso, daremos alguns passos atrás buscando reconhecer os processos que levaram ao atual panorama. Iniciaremos, pois, explorando diferentes momentos a partir da década de 1990, em que se iniciava um processo criativo de reinvenção da cultura no Acre, explorada por diversos autores (Carid Naveira, 1999; Lagrou, 1991; Weber, 2006) e o momento atual, em que os Pano estão viajando pelos centros urbanos para "apresentar a cultura". Por esse motivo, colocamos especial atenção em algumas de suas expressões estéticas.

Acompanharemos esses novos movimentos, analisando como as religiões ayahuasqueiras (principalmente o Santo Daime) e os indígenas pano se afetam mutuamente. Destacaremos a relevância das mesmas no que chamaremos aqui de "fortalecimento da cultura", 7 justamente porque contempla em seu processo social a ativação de práticas próprias para produção de corpos duros, resistentes, belos e propriamente huni kuin ou yawanawa (Ferreira Oliveira, 2016). $\mathrm{E}$, ainda, porque sinaliza que apesar de haver diferentes movimentos entre

7 Esse processo também é chamado pelos indígenas de "florescimento", "renascimento", "resgate", "revitalização" ou "reavivamento" da "cultura"- nesses movimentos contínuos que esses grupos estão fazendo de uma retomada (e inerente transformação) do que chamam de "usos" da "cultura", ao se referirem às festas, rituais, línguas, artes, etc. 
o que seria a "retomada da cultura" (enquanto momento inicial, geralmente pautado em ações voltadas para o "interior") e a "apresentação da cultura" (por meio de uma performatividade que se comunica com "externo"), esses processos ocorrem em simultâneo por conta da produção de um efeito looping (Hacking 1996, apud Carneiro da Cunha, 2009), em que os sujeitos "têm consciência sobre como são classificados" e que "essa consciência tem efeitos próprios [...] onde passam a se comportar de modo estereotipado, como se espera que o façam" (Carneiro da Cunha, 2009, p. 363). Ainda, segundo a autora, essa reflexividade tem efeito dinâmico sobre aquilo que reflete (a cultura) e as próprias categorias de metadiscurso (a "cultura"), uma vez que operam como categorias de ida e volta (Carneiro da Cunha, 2009, p. 311).

Mais do que centralizar a análise em algum grupo, aldeia ou indivíduo específico, tomamos a ayahuasca, ${ }^{8}$ o daime, o uni e o nixi pae como mediadores (Calavia Sáez, 2014) propiciadores de configurações diversas, heterogêneas, em constante movimento e transformação, que vão tecendo suas malhas, conectando aldeias indígenas no Acre a diversas cidades do Brasil e do mundo. Conectam-se, assim, mundos diversos - indígenas e não indígenas, humanos e de gentes outras. Portanto, nossa narrativa nos guiará pelo questionamento: quais forças são estas, trazidas pela festa e pela ayahuasca, e como se expressam em termos de alianças e rituais de pajelança? Façamos um sobrevoo pela floresta, sem garantia de aterrisagens, tampouco de apresentar mais respostas do que perguntas.

\section{Da cidade para a floresta: cantos de ida e volta do daime}

[...] Começou a renascer a cultura, os usos em geral, o ritual, a dança, os costumes [...] antes a cultura tava ficando no espaço, ninguém correspondia. Acabou por causa da correria. As medicina da floresta tava deixado, esquecido. Antes da conquista da terra, não podia produzir nossa cultura. [...] Seringalista era dono da terra, nós indígenas não podia fazer nada para vocês, só para ele. (João Sales Kaxinawá, in memoriam, em conversa no I Festival Xina Bena em 2010).

8 A ayahuasca é produzida a partir da cocção do cipó Banisteriopsis caapi e da folha Psychotria viridis. 
Em um dos movimentos de ida para as cidades, o cipó se encontra com seringueiro nordestino Irineu Serra que recebe a divina missão de fundar a doutrina do Santo Daime. Versões indígenas desse encontro variam sobre quem ${ }^{9}$ teria "apresentado o cipó" para ele, mas coincidem em afirmar que "recebeu o chá da mão dos índios". Surge, a partir da revelação da Virgem da Conceição, um novo mestre e uma nova bebida, de nome e de ontologia próprios, com sua "força" trazida no dizer "dai-me luz". Essa questão pode ser mais bem verificada nas palavras de Buse Huni Kuin (Cosmo), da aldeia do iguarapé do Caucho:

[...] O Santo Daime, depois que padrinho Irineu recebeu a doutrina, ele santificou a ayahuasca, né, que é nixi pae como Santo Daime né, porque ele encontrou que o Santo Daime é um ser divino, hoje traz ensinamentos, seguimentos de bem pra humanidade.

Até o presente momento, a literatura antropológica de xamanismo urbano (Magnani, 2000) ou neoxamanismo (Caicedo Fernandez, 2007) tem destacado como seus praticantes veem os indígenas enquanto detentores de uma "sabedoria antiga" e "ancestral" que foi transmitida "de geração a geração". Notamos essas mesmas apreciações em contextos recentes no Brasil onde alguns indígenas são bastante atuantes (Coutinho, 2011; Ferreira Oliveira, 2009, 2011, 2012; Labate; Coutinho, 2014; Lima; Labate, 2007; Rose, 2010). Para entender como esses indígenas adentram os meios urbanos através do cipó, é necessário que observemos processos anteriores ao atual movimento de "mostrar a cultura".

Nas cidades próximas às aldeias, como Rio Branco, Tarauacá e Cruzeiro do Sul, há diversos grupos ayahuasqueiros, sendo alguns deles sedes das religiões ayahuasqueiras (Santo Daime, Barquinha, União do Vegetal) e outros não religiosos. Esses locais são frequentados por indígenas (porém não enquanto oficiantes de rituais na modalidade a que aqui nos referimos). Essas relações foram determinantes nos processos de reinvenção da cultura engendrados por distintos grupos indígenas da região. Como nos conta Carlos Assen Carvalho,

9 Para mais detalhes acerca das (aparentemente) recentes versões sobre o mestre ter conhecido o chá com indígenas, e não um "índio peruano", ver Ferreira Oliveira(2011) e Labate e Coutinho (2014). Há versões que afirmam ser Sueiro Sales, enquanto outras apontam para um grupo em que estavam Pedro Kuntanawa, Samuel Pianko, Crispim Shawadawa e Adalto Huni Kuin. 
padrinho da igreja daimista Centro de Luz do Juruá, sobre seu encontro com algumas lideranças pano em 1990, em Cruzeiro do Sul, onde o chá era tomado com instrumentos musicais e animação:

Eu conheci o Bira naquele momento, o Biraci [Yawanawa], o Siã [Kaxinawá], o Macedo. Nesse tempo que a gente estava tomando o chá lá eles apareceram foi na época que foi levantada a história do movimento indígena aqui na região. Quando o Macedo veio para cá na época de 1988, por aí. Aí quando foi em 90 o Mirim chegou por aqui, em 91, com a história do chá, tomava chá, era um pessoal que era eclético. O Macedo já conhecia o chá, de Rio Branco [...] no Alto Santo. ${ }^{10}$ E aí o Mirim veio fardado também com o Padrinho Sebastião. E esse pessoal vindo para cá, como esse movimento indígena estava começando em Cruzeiro do Sul, botaram o chá na frente, começaram a fazer chá e tomar. E aí o ponto de encontro foi lá no quintal desse Macarrão. O quintal que era aberto, legal, tinha um chapéu de palha atrás. A gente tomava chá naquele terreno limpo. A gente cantava, tocava, tinha fogueira, então era curtição. $E$ aí começou a história desse movimento. (Entrevista em Cruzeiro do Sul, em 2011).

Carlinhos, como é conhecido, conta que iniciou tomando o cipó com indígenas nessas ocasiões. Assim, aos poucos foi "ouvindo a notícia" da existência do Santo Daime, e, em 1994, fundou a igreja em Cruzeiro do Sul, chamada Centro Luz do Juruá. Nessa época frequentaram sua igreja lideranças dos Huni Kuin, Yawanawa, Ashaninka, Katukina, Kuntanawa, para juntos tomarem "daime de rede"11 - em referência às redes utilizadas pelos indígenas. Na opinião de Carlinhos, o Santo Daime "trouxe a luz" e teria contribuído efetivamente para que essas lideranças passassem a valorizar e praticar os rituais com ayahuasca em suas aldeias. No contexto desses encontros, algumas dessas lideranças, por sua vez, incentivaram os Puyanawa a também retomarem o uso da bebida, como foi o caso do shaneihu (cacique) yawanawa Biraci Nixiwaka, da aldeia Nova Esperança. Portanto, o processo de "fortalecimento da cultura" entre os Yawanawa

10 Alto Santo é a linhagem do Santo Daime fundada pelo mestre.

11 Se, nos modos indígenas do uso do chá, temos o "daime de rede", nos xamanismos nas cidades temos um círculo no chão, e o Daime, por sua vez, tem rituais tipo bailado (com dança) e de concentração (onde se usam cadeiras). 
reflete-se, hoje, tanto nas próprias práticas do grupo quanto na sua expansão para outros grupos pano: os Puyanawa, os Kuntanawa e os Nukini, que em processos semelhantes incorporaram certa estética dos Yawanawa (com os saiti ${ }^{12}$ e longos cocares).

Nesses encontros entre lideranças indígenas e ayahuasqueiros locais, o movimento indigenista foi fundamental no processo de valorização da cultura indígena e do cipó. Além dos programas de formação indígena na Comissão Pró-Índio do Acre, notamos que os usos seringueiros foram determinantes nesse movimento que se iniciava no Vale do Juruá. Nas mencionadas rodas de cipó no Macarrão, ${ }^{13}$ o sertanista Antônio Macedo trazia para as rodas suas canções no violão, sendo algumas do Santo Daime e outras do Nordeste. Outros indigenistas de vanguarda que foram fardados na doutrina no Alto Santo, como Terri Aquino e Dedê Maia, ${ }^{14}$ tiveram papel central no movimento de "valorização da cultura". Macedo, juntamente com Mirim e o cipó, "animaram os terreiros", como ele conta:

No tempo do cativeiro conheci vários povos indígenas que já não praticavam o uso da ayahuasca. Puyanawa, Nukini, e até os Shawadawa. Servi a eles os primeiros copos de ayahuasca. Os orientei e eles seguiram [...]. Comunidades inteiras que se livraram do álcool que bebiam antes.

Ainda, atualmente são diversos os relatos de jovens indígenas que foram motivados a tomar o chá a partir de membros de religiões ayahuasqueiras. Em um "movimento pró-cultura" entre os Huni Kuin do rio Humaitá, passou-se a notar um maior espaço para o mariri (que atraía por sua "animação"), o aumento das sessões de cipó e a proliferação de cantores (Weber, 2006, p. 150). Weber (2006) analisa esse momento de surgimento de um grupo de jovens huni kuin que decide formar uma igreja na aldeia Novo Futuro, chamada União, fundada

12 Segundo Carid Naveira (1999) parte das canções dos Yawanawa são de origem noke koi (katukina pano) e kulina. Entretanto o que os Yawanawa chamam de saiti, os Noke Koi chamam de txiriti, referindo-os como mariri, enquanto para estes o saiti é somente para cura. Os Yawanawa têm diferentes tipos de saiti, alguns para festa e outros para cura (como vana saiti).

13 Este era farmacêutico em Cruzeiro do Sul.

14 Entretanto vale ressaltar que Dedê conheceu o cipó com os Huni Kuin, e Macedo, nos seringais. 
em 2000 com o objetivo de ter como centro o nixi pae ${ }^{15}$ (sendo que, até então, eles tomavam essa bebida principalmente nas festas de forró). Posteriormente, ainda nesse movimento alguns deles participaram em trabalhos em distintas "casas". Ninawa Pai-da-Mata iniciou o movimento enquanto pajé, e hoje assume também a liderança política depois que seu sobrinho Tuim Nova Era passou a viver em outra aldeia: constituindo-se, portanto, um movimento novo já que entre os Huni Kuin se costuma diferenciar a chefia política e xamânica (Carid Naveira, 1999, p. 76-80).

Segundo Ninawa, depois de alguns anos de atividades, fecharam a União para começar o "trabalho na cultura". Ele explica que, fazendo suas primeiras viagens, percebeu que os nawa estavam mais interessados na cultura huni kuin do que no Daime: "Não era bom sair por aí mostrando algo que não é a cultura, que não é nosso", diz Ninawa. Atualmente, uma vez que a "cultura já está mais fortalecida" - e com seu festival na quinta edição, tendo viajado por diversos países (Alemanha, França, Holanda, Finlândia, Estônia, Espanha, Estados Unidos, etc.) -, Ninawa já planeja construir novamente uma igreja do Daime, devido à sua importância nesse processo. Essa intensa apropriação de elementos religiosos ayahuasqueiros é também perceptível em algumas aldeias ao longo do rio Jordão, que fazem um uso individualizado do maracá e o tocam em um ritmo que se assemelha àquele do Santo Daime.

O movimento na aldeia Novo Futuro foi um exemplo para os Huni Kuin do Caucho que foram visitá-los no rio Humaitá e passaram a tomar caminho semelhante. Contam que sabiam da existência do cipó, porém "os velhos não falavam nada, nessa época, ninguém não conhecia", conta Cosmo Busê, uma jovem liderança fardada nessa aldeia na municipalidade de Tarauacá. O nixi pae estava "deixado de canto". Um primeiro "despertar" deu-se a partir da União do Vegetal, que buscava cipó nesta aldeia - o que atraiu o olhar e interesse de jovens indígenas na bebida. Aos poucos foram recebendo estímulos das igrejas ao redor do Alto Santo, e em 2006 decidem fundar uma igreja, enquanto um modo de

valorização desse segmento, do trabalho da doutrina, que liga dentro da cultura huni kuin. Então, essa semente se liga, universalmente, a cultura e a doutrina.

15 Vale notar, portanto, uma configuração própria das religiões ayahuasqueiras que têm como centro e seu fundamento o uso da ayahuasca. 
[...]. Tanto a cultura e a doutrina, é um mesmo espelho. Porque nasceu da mesma semente. A doutrina veio também ligada dentro da cultura do povo indígena. Então a gente achou que encaixou, duas fontes de conhecimento igual.

Siã, irmão de Busê, conta ter participado em diversos trabalhos nas religiões ayahuasqueiras mencionadas: no Santo Daime da Cicluju, ${ }_{16}^{16}$ do Centro Livre, do Padrinho Luis Mendes, e na Barquinha da Madrinha Chica. Conta que foi assim que pegou "instrução" e trouxe para seu povo um "padrão para trabalhar". Interessante notarmos o mesmo princípio entre os Huni Kuin da aldeia Novo Futuro e do Caucho, em "separar" o que é "trabalho da cultura" e "trabalho da doutrina". Esse parece ser um modo propriamente huni kuin de incorporar esses "segmentos", nas palavras de Cosmo Busê:

No terreirão sagrado a gente canta mais as cantorias, da cultura indígena [...] Quando é hinário normal, da doutrina, trabalha é só na sede mesmo. A gente não mistura pra ficar melhor. Pra organizar o trabalho melhor. [...] Mas esse período de festival a gente trabalha mais a cultura.

Observando os distintos modos de relacionar-se com as alteridades, atuando com mecanismos de abertura e contenção dos fluxos do Daime nas aldeias, as ações dos Yawanawa são um tanto diferente das dos Huni Kuin. Embora as estreitas relações das lideranças yawanawa (principalmente Nova Esperança) com distintos segmentos do Santo Daime, há certo controle quanto ao uso de hinos na aldeia (Ferreira Oliveira, 2012).

Lideranças da aldeia do Mutum, por sua vez, criticavam esses movimentos de incorporação de elementos do Daime que ocorriam nessa outra aldeia, como o uso de danças durante o ritual de uni, que eles relacionam à influência do bailado do Santo Daime, enquanto seus ancestrais diziam que uni se toma em silêncio e sem danças. A ideia de "bagunça", "zoada", "mistura" - que podemos em certa medida associar a ânimos da festa - aparece como algo inicialmente destoante do uni.

Ao contrário de alguns Huni Kuin - que se fardam no Santo Daime com certa recorrência - essa prática é incomum aos Yawanawa. Tampouco nota-se

16 Centro de Iluminação Cristã Luz Universal de Juramidam, em Rio Branco. 
a presença de altares, como entre os Huni Kuin. Apesar de suas intensas alianças com diversos segmentos do Santo Daime, locais (como com Davi, no rio Croa), no Rio de Janeiro ou no exterior, como no Canadá e na Europa, o cacique yawanawa Biraci, em certa ocasião "viu" na "força" do uni que ele não devia se fardar. Kuni Yawanawa, um dos poucos Yawanawa que foi fardado, conta que a jiboia "jogou muito contra seu fardamento" ao travar um tenso diálogo com ele na igreja (ver Ferreira Oliveira, 2012). Portanto, restringir a entrada de elementos daimistas - como seus hinos, danças, fardamento e objetos como o maracá é um dos meios de contenção desse fluxo (provavelmente frente à sua longa experiência com os missionários, o que com os Huni Kuin se deu de forma menos ostensiva). Quanto aos modos de abertura dos Yawanawa, em especial falando do padrinho Paulo Roberto do Rio de Janeiro, notamos dois momentos. Primeiramente, a aliança com o cacique Biraci, que durou entre 2009 e 2014, com seu projeto (interrompido) de grande porte com a Google na aldeia Nova Esperança. Em um segundo momento, uma aliança com alguns membros da aldeia do Mutum, quando Jordão, o filho de Paulo Roberto, casa-se com Kenewma, filha da cacique Mariazinha com o cacique Biraci. No caso da aldeia do Mutum, com pregressas críticas quanto ao Santo Daime adentrar as práticas yawanawa, foi via parentesco que a aliança com o Daime se consolidou. Por outro lado, a incorporação huni kuin do Santo Daime dá-se como um impulso reverso, como via para "fortalecimento da cultura". Entretanto, até o momento não se notam, por exemplo, casamentos entre Huni Kuin e nawa ${ }^{17}$ (que por sua vez têm se tornado comuns entre lideranças yawanawa do Mutum e outros nawa com os quais fazem rituais nas cidades).

O cacique geral dos Huni Kuin do Jordão, Siã Osair Sales Kaxinawá, foi um dos primeiros indígenas a se fardar no Alto Santo. Era no início da década de 1990, quando alguns indígenas buscavam no Santo Daime um contato inicial com a bebida. Na década seguinte, Siã foi determinante na criação do primeiro festival huni kuin, e seus filhos Fabiano e Leopardo foram precursores na expansão do nixi pae para cidades do Brasil e do mundo. Em consonância com as afirmações do padrinho Carlinhos acerca dos "encontros dos povos" que aconteciam no quintal do Macarrão, Siã conta que seu fardamento deu "luz"

17 Exceção ao caso foi o casamento entre o daimista e indigenista Eduardo Bayern (in memoriam) e Lucilda Huni Kuin. 
e "força" para sair do "vício" do álcool. Afirmação esta que é recorrente entre diversos grupos pano na região, alguns atribuindo diretamente às suas experiências com o chá. Falando do que levou ao fardamento, Siã afirma que tinha vontade de utilizar a "farda" (vestimenta daimista) para estar "arrumado". "Nós também temos nossa farda" - referindo-se à vestimenta huni kuin, chamada samputare (uma espécie de vestido) keneya (com desenhos).

Notamos elaboração muito semelhante no relato de um Yawanawa, em relação a suas motivações para fardar-se e se "apresentar bonito" (Ferreira Oliveira, 2012). Podemos pensar a questão do fardamento a partir da noção de imitação (vestir-se como o outro e vestir-se conforme) e como uma forma de aprendizado, ou mesmo de relação com a alteridade. Conforme Weber (2006) afirma ser a "captura" um modo dos Huni Kuin adquirirem certas habilidades de espíritos e animais, assim como as histórias dos antigos (shenipabu) contam como conhecimentos, alimentos, etc. foram apropriados dos yuxin ("espíritos") pelos Huni Kuin (Lagrou, 2007). Já com relação aos Yawanawa, sabemos também que alguns de seus cantos e brincadeiras eles aprenderam de outros povos, em contexto de festa e guerra (Carid Naveira, 1999). Seria, portanto, dar continuidade a esse modo de captura, tornando possível a incorporação dos conhecimentos dos nawa (já que estes ocupam atualmente, pelo menos na festa, posição semelhante dada à alteridade, já que eram outros grupos indígenas os visitantes nos antigos mariri dos Yawanawa).

De toda forma, é própria do xamanismo a incorporação de técnicas distintas, como o uso de determinadas plantas, que circulam à medida que os grupos indígenas estabelecem redes e relações. Do mesmo modo, a partir do momento que se estabelecem alianças com os nawa, através do xamanismo, é de se supor que o padrão de absorção das habilidades e técnicas do outro continue a operar. Com "montagens de outras técnicas", os xamãs "reúnem em si mais de um ponto de vista" (Carneiro da Cunha, 2009, p. 112). O fardamento de Virgulino Ixã, liderança huni kuin da aldeia Altamira, no rio Tarauacá, aponta para os mesmos sentidos. Conta que gosta de utilizar a "estrela" (broche de ouro utilizado no peito, recebida no ato do fardamento), pois assim pode "tomar mais nixi pae". Segundo ele, a estrela tem o poder de "estabilizar" a experiência com a bebida de modo a não "provocar" (i.e., vomitar). Ainda para Ixã, a estrela teria a potência de produzir luminescência nas visões: "é muito mais luz!". 
Ixã conta que se fardou na igreja da comunidade Céu do Patriarca São José, em Florianópolis, a convite do padrinho Enio Staub, com quem já mantinha uma amizade de anos. Ixã recorda que o padrinho lhe falou: "Você já é fardado na sua tradição, agora você farda no Daime." Ixã conta ter aceito o convite, e argumenta: “Também tem nawa que já fardou na cultura, já sabem as músicas, pode ser outras coisas, cantador, txana." Ainda, notamos ser recorrente nas falas de algumas lideranças huni kuin a importância de construir uma estrutura, enquanto uma igreja, em um movimento diplomático de agradecimento ao Santo Daime.

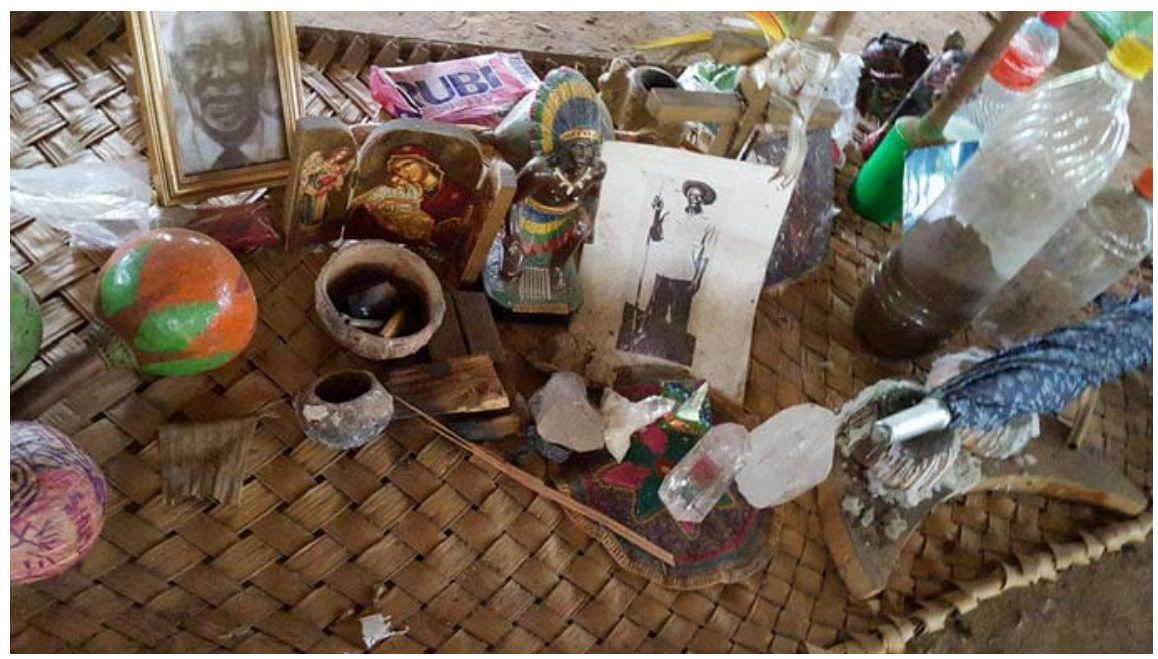

Figura 1. Altar na “igreja” da aldeia Altamira (foto da autora, rio Tarauacá, 2017).

\section{Festa como festival}

Chaumeil (2012) propõe que na esteira dos vários booms que sacudiram a Amazônia ao longo de sua história - como o caucho, a seringa, o petróleo, o ouro e a coca (e agora, talvez, a ayahuasca) - o turismo poderia ser pensado como o mais recente deles. Segundo alguns autores, o turismo místico ou xamânico e o ritual da ayahuasca se incrementaram nos últimos anos a ponto de se tornarem uma verdadeira indústria (Galinier; Molinié, 2006 apud Chaumeil, 2012). Quanto aos festivais no Acre, a maioria dos nawa conhecem os indígenas 
em rituais nas cidades, e geralmente "ir para a floresta" é tido como um segundo momento em sua "caminhada espiritual". Portanto, as agências de turismo desempenham um papel secundário e atuam enquanto canal de comunicação conectando os nawa (que não estão envolvidos com uso urbano da ayahuasca ou com a "cultura indígena" por meio de projetos) com os indígenas (que querem receber visitantes mas não dispõem de "contatos" e redes estabelecidas nas cidades).

Como veremos, observando o êxito das festas dos "parentes" yawanawa (com seu primeiro festival em 2002) e sua consequente abertura a novas possibilidades de projetos e "expansão da cultura", os Huni Kuin do rio Jordão - pioneiros nessa inserção expressiva de rituais pano nas cidades -, realizaram seu primeiro festival em 2010. Nos anos seguintes, novos festivais foram surgindo, em diferentes rios, oferecidos por distintas aldeias huni kuin (do Humaitá, Caucho, etc.) e atualmente contamos com as primeiras edições de festivais dos Puyanawa, Shanenawa, Nukini e Shawadawa. Estamos, pois, diante do que mencionamos ser um efeito looping, em que a ayahuasca, com seu conhecido potencial turístico acerca da "cultura indígena", leva certos grupos a consumirem mais ayahuasca. Isso porque a busca dos nawa por tomar "medicinas" diariamente, quando estão nas aldeias, diverge de modos de uso locais, levando os indígenas a atenderem uma demanda que os aproxima das igrejas ayahuasqueiras, que são as principais produtoras da bebida (especialmente, pois os nawa querem bebidas fortes, como o conhecido "mel" de concentração apurada).

Entre os Yawanawa, as brincadeiras que fazem parte do uma aki (ver Carid Naveira, 1999) são o que anima seus festivais. Já os Huni Kuin selecionaram o katxanawa - onde se canta e dança para "chamar a força dos legumes" - como a principal festa de seus festivais. A partir da primeira década deste século, essas festas tiveram um papel central na reinvenção de práticas até então "abandonadas". Como disse João Sales Kaxinawá: "A cultura estava ficando no espaço." A "animação" traz alegria e envolvimento, por isso as festas têm sido dispositivo fundamental no "fortalecimento da cultura" no Acre. Seja no mariri yawanawa ou huni kuin, a maioria das brincadeiras exerce um papel fundamental nos casamentos entre afins. Incitados por xingamentos mútuos (relativos aos órgãos sexuais) e embates variados (com corpo, fogo, água, gravetos, etc.), os potenciais cônjuges se aproximam (Carid Naveira, 1999; Lagrou, 1991, 2007; Weber, 2006). 


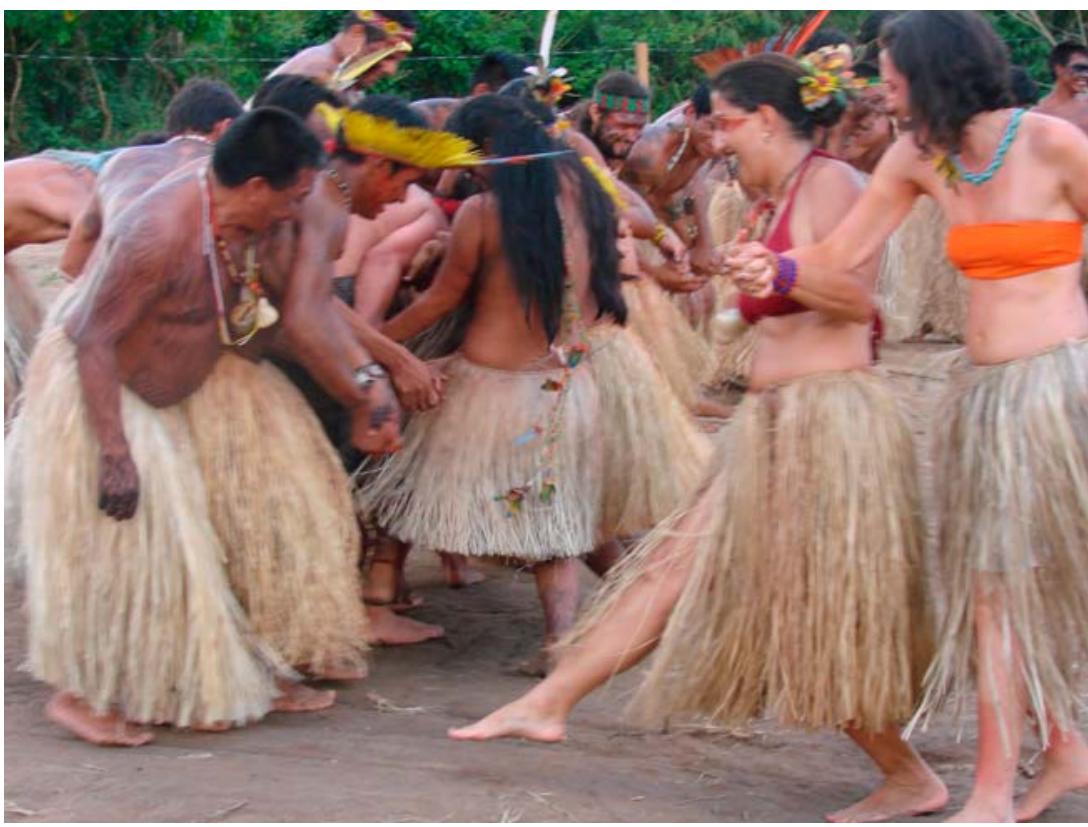

Figura 2. Brincadeira kia (pé) ashunu (pisar) no Festival Yawa (foto da autora, 2011).

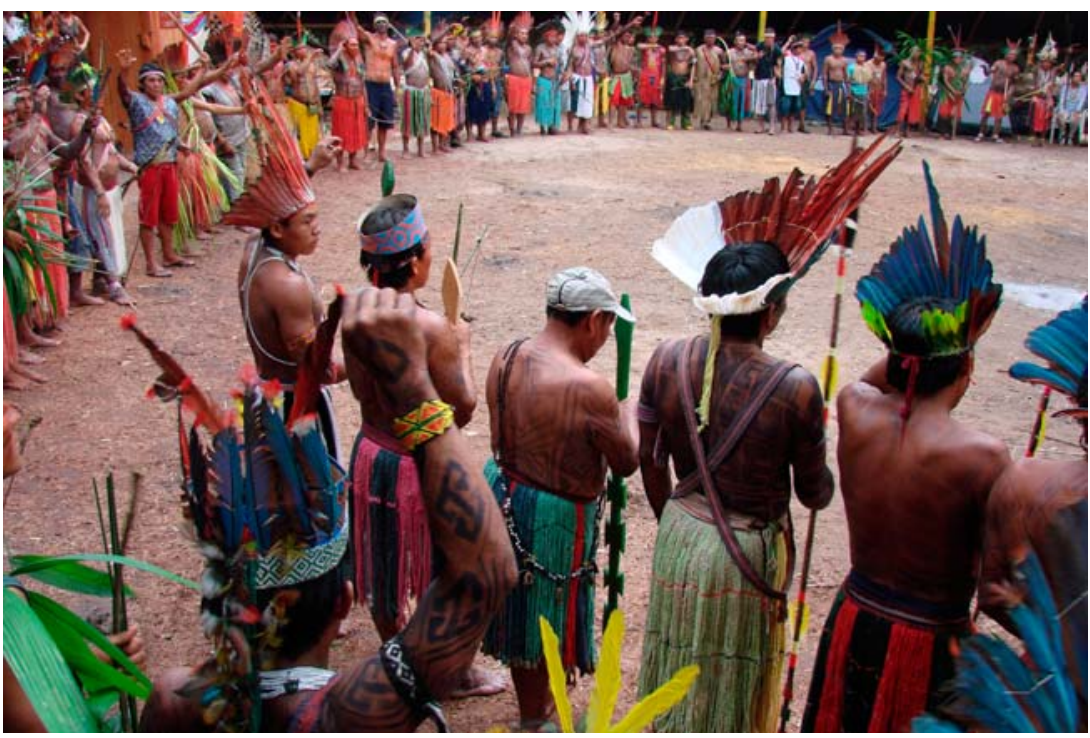

Figura 3. Roda de katxanawa no I Festival Xina Bena (foto da autora, 2010). 
Portanto, de forma geral, atribui-se ao Festival Yawa a influência sobre os demais. Entretanto, alguns Yawanawa atribuem aos Ashaninka certo pioneirismo nas festas. Aqui não consideramos enquanto "festival" a festa ashaninka que ocorre em meados do ano, pois, apesar de contar com convidados não indígenas do Brasil e exterior, diferencia-se desses eventos aqui analisados porque é apenas para convidados; portanto não é um evento aberto, no qual se participa mediante pagamento. Importante ressaltar que os Yawanawa atribuem aos Ashaninka a forma atual como fazem a "caiçuma forte" (fermentada), quando estes, em 2002, no primeiro festival, ensinaram seu modo de prepará-la. Dizem que optaram pelo modo ashaninka e não pela forma dos antigos yawanawa, em que as mulheres mascam a macaxeira a fim de fermentá-la, por questões de praticidade e rapidez.

Tais festivais, portanto, derivam de um modelo ${ }^{18}$ de festa criada pelos Yawanawa. Desde então muitos parentes vêm visitando seus festivais, "importando" o modelo (baseado em uma programação, estrutura, logística, etc.) para suas aldeias. Essa celebração do "renascimento" yawanawa foi inicialmente concebida como um dispositivo para relembrar suas festas, canções e enfeites, fazendo frente à coibição de suas práticas pela missão Novas Tribos do Brasil, que permaneceu durante décadas nas aldeias yawanawa. Segundo Sales Yawanawa: "Os Yawanawa não conheciam seus enfeites, suas danças. Foi um improviso." Isso se deu a partir da curiosidade dos jovens, que consultaram os velhos que já haviam estado nos mariri de antigamente: Tuinkuru, Yawarani, Gatão (Tatá), Dona Nega, e outros. Os Noke Koi (Katukina), por sua vez, afirmam que ensinaram os Yawanawa a fazer mariri, quando na década de 1990 os Yawanawa os convidavam para brincar na aldeia Nova Esperança. A primeira experiência foi uma festa mais "interna", e é relembrada pelos Yawanawa com muita emoção, onde se mesclaram sentimentos de orgulho de ser Yawanawa com curiosidade, graça, timidez e vergonha (no caso das mulheres, com troncos vestidos somente de urucum). Nas edições seguintes, o Festival Yawa logo "se abriu" e se tornou um evento voltado também aos visitantes nawa.

18 A estrutura do festival (de dia com brincadeiras, e de noite com ritual de cipó) é uma invenção recente, tendo em vista depoimentos de lideranças yawanawa e noke koi (katukina), de que não havia sessões de cipó durante os mariri, e as brincadeiras adentravam a noite. 
De modo geral, os festivais surgem como uma forma de festejar ao modo "como os antigos faziam", em um potente dispositivo de "retomada" da cultura (que continua ocorrendo com outros grupos atualmente, fazendo seus primeiros festivais ${ }^{19}$ ). Outros eventos, como o "Encontro de Culturas", que ocorriam no Acre, ou um encontro de lideranças indígenas promovido por Ailton Krenak na Serra do Cipó (MG), também foram relevantes para pensar essa concepção de festival. Sua criação contou com inspirações externas, como a participação da liderança yawanawa Tashka em um pow-wow nos Estados Unidos. Segundo Lanternari (1974, p. 121-122), os pow-wow são

reuniões inter-tribais periódicas, de caráter religioso e festivo, que se realizam durante vários dias seguidos, até por uma semana inteira, e nas quais a atividade premente constitui de danças coletivas. [...] A forma das danças, pop-wow, além da música, representa uma síntese moderna de elementos tribais e americanos; [...] De fato, a atração particular dessas reuniões consiste em que os convidados se sentem solidários, fora do consórcio dos brancos, para agirem como índios.

Como sabemos, na época dos seringais, o sentimento de vergonha levava os indígenas à tentativa de diluírem-se entre os cariú (brancos) em torno da categoria de caboclo - o que ocorria em grande medida porque eram "mangados" pelos não indígenas locais, por "cortar gíria" (isto é, falar em suas línguas indígenas) (Carid Naveira, 1999; Weber, 2006). Em um movimento inverso, como efeito looping da retomada do cipó nas aldeias (dentre outros fatores), o uni e nixi pae atuam como principais impulsores no "fortalecimento da cultura", agora em uma iniciativa de distanciar-se da categoria "caboclo" e serem identificados como "indios". Assim, estes passaram a rejeitar tal denominação. Como efeito looping de suas andanças pelas cidades, tal categoria passa a novamente ser considerada, assumindo para os mesmos novos sentidos. Isso porque, durante seus rituais nas cidades, os indígenas deparam-se com um "caboclo" que é indicativo de sabedoria e conhecimento ancestral sobre a mata e os processos de cura, associado a um imaginário urbano ligado às influências e intersecções

19 Segundo Zezinho Yube, da assessoria de assuntos indígenas, em 2018 o Governo do Estado do Acre apoiará a realização de 40 festivais. 
entre religiões afro-brasileiras, com a Nova Era, o Santo Daime, o Umbandaime, a Barquinha, etc. Situação em que as experiências dos pajés em nível "global" transformam o "local".

Nas apreciações de Nani Yawanawa quanto aos festivais, ele afirma que os nawa são amigos que "só fazem inteirar os Yawanawa" e "encorajar a festa": os visitantes "fortalecem" e "dão mais energia" aos anfitriões. Além disso, considera que são "parte de uma família que está chegando". Ademais, o fato de os indígenas atraírem visitantes, bem como estarem circulando nas pequenas cidades do Acre com seus novos amigos "do sul" e/ou "gringos" fez com que seus vizinhos nawa repensassem as atribuições que faziam e os tratamentos direcionados aos indígenas. Para pensar em maiores escalas, remetemos a afirmação da liderança yawanawa, que "se não existissem os que vêm de fora", não haveria tanto interesse governamental em dar suporte aos festivais: "Todo mundo tem ego, quer mostrar o que faz, sentir-se importante, se fosse só nós, não ia ter esse apoio."

Portanto, novos caminhos pelas cidades levam os indígenas a construir novas possibilidades de autonomia: dispensando mediadores, podem receber seus amigos e fazer "trabalhos espirituais". Isso ocorre porque há uma grande demanda urbana por conhecer as "medicinas da floresta", uma vez que até então nos centros urbanos vigorava uma predominância de movimentos de Caminho Vermelho, enquanto um universo de seres e conceitos que circulam entre matrizes diversas, associados a práticas e discursos sobre uma "tradição" atribuída a indígenas norte-americanos, mesoamericanos e andinos (Ferreira Oliveira, 2009). Traçar caminhos fora do Acre possibilita resolver questões locais sem contar apenas com a distribuição de benfeitorias de lideranças ou instâncias superiores..$^{20}$ Com seus festivais, os Yawanawa e Huni Kuin estão trazendo novos personagens eminentes, favorecendo seu poder de negociação e formação de alianças com antigos parceiros locais. Em suma, a ayahuasca, o xamanismo e os festivais vieram trazer um novo modo de atuação, que antes ficava restrito ou ao mundo dos "projetos" como via única de produção de mudanças nas aldeias ou às benfeitorias do governo (que acabam sendo

20 Esse seria o caso de Ninawa da aldeia Novo Futuro, que encontrou uma frente de atuação própria e desvinculada da chefia política da aldeia São Vicente. 
restritas às famílias indígenas mais influentes e com maiores alianças com os políticos e outros setores atuantes na região).

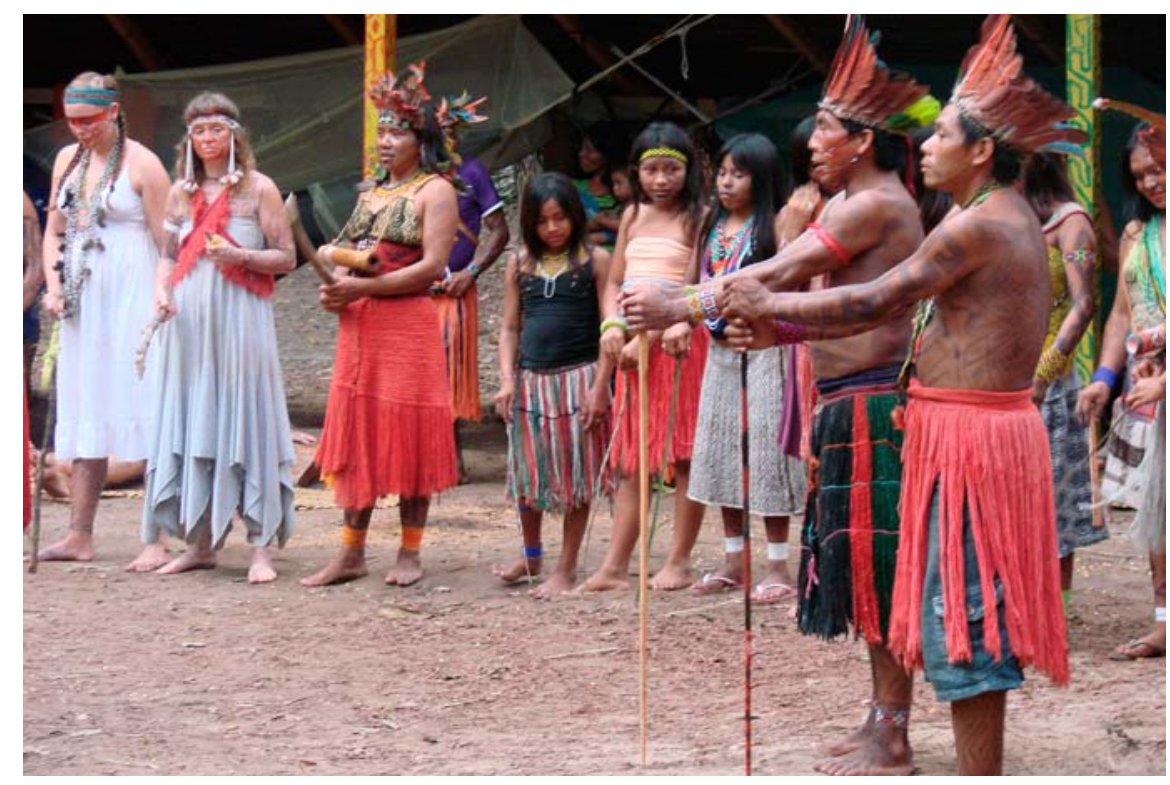

Figura 4. Início de brincadeira de katxanawa (foto da autora, 2010).

Os Huni Kuin fazem também festas internas, que usualmente não são chamadas de festival, e sim pelo nome próprio a cada festividade. Se o katxanawa não é a atividade central e temática do festival, geralmente aparece como parte fundamental da festa. Mais recentemente, outra festa que assume ${ }^{21}$ caráter de festival entre os Huni Kuin é o nixpupima referenciado pelos mesmos como sendo um "batizado". O katxanawa celebra a invasão dos estrangeiros: os yuxin ("espíritos") se aproximam, escondendo-se com folhas de jarina (Lagrou, 2004). A escolha por celebrar a chegada dos yuxin parece não ser gratuita, pois, ao evocá-los, os Huni Kuin estão acionando seus conhecidos

21 Não se considera o nixpupima como mariri, e sim "festa de batismo". 
modos de relacionar-se com as alteridades. Como descreve Lagrou (2004) os yuxin encenados por uma das metades (inu, "onça") chega, como invasor, cantando ho ho ho ho. A outra metade, yube (jiboia), enfrenta os invasores, que mostram a face e suas intenções pacíficas. Ao final, todos dançam juntos e se divertem, e depois as posições se invertem. Considerando que muitos rituais amazônicos "encenam a chegada de visitantes que encarnam uma larga série de formas e matizes da alteridade: povos aliados ou inimigos, homens brancos, animais, espíritos, antepassados, mortos" (Calavia Sáez; Arisi, 2013, p. 207, tradução minha), a forma como se dá o encontro com os yuxin no katxanawa bem pode ser pensada em analogia com suas recentes relações com os nawa (inicialmente enquanto invasores, nos seringais, e, em um segundo momento, em uma aproximação amistosa, em que os nawa se interessam pela cultura indígena).

Se é sabido que o katxanawa tem o poder de trazer alegria a momentos de tristeza na aldeia, bem como "levanta a moral da comunidade" (Lagrou, 2007, p. 421; McCallum apud Weber, 2006, p. 185) entre as famílias huni kuin, podemos dizer que esse mesmo dispositivo segue operando, no que se trata de festivais que recebem muitos gringos. Ainda, o modo de interação próprio do katxanawa, que conta com improvisações que fazem parte do "aprender a brincar", faz com que as explicações dadas pelo txana (especialistas dos cantos e brincadeiras) aos nawa antes de começar cada brincadeira sejam parte de uma dinâmica já conhecida por eles.

Durante o katxa, o participante deve se envolver, brincar tanto quanto puder, sem se deixar vencer pelo cansaço. Quando começa a anoitecer, a brincadeira chega ao fim. Nesse momento, durante o I Festival Xina Bena, um nawa recebeu um cocar de Ibã Kaxinawá, que, mesmo sem conhecê-lo, ofertou-lhe discretamente o presente como forma de reconhecimento de sua resistência. Nesse sentido, vale considerar que o ato de entregar e vestir um cocar, diante dos olhos de todos, é uma performance utilizada durante os festivais, como forma de realizar solenidades. Esse é um indicativo de como os indígenas operam com analogias, de modo a aproximar e, por vezes, igualar, o que antes eram papéis bastante distintos: pajé, professor e chefe (shane ihu/shane ibu) podem também ser associados a um padrinho ou madrinha do Santo Daime. É pertinente pensar sobre os efeitos dessa aproximação, uma vez que, levando a sério a analogia, o "padrinho" congregaria ambos os papéis. 


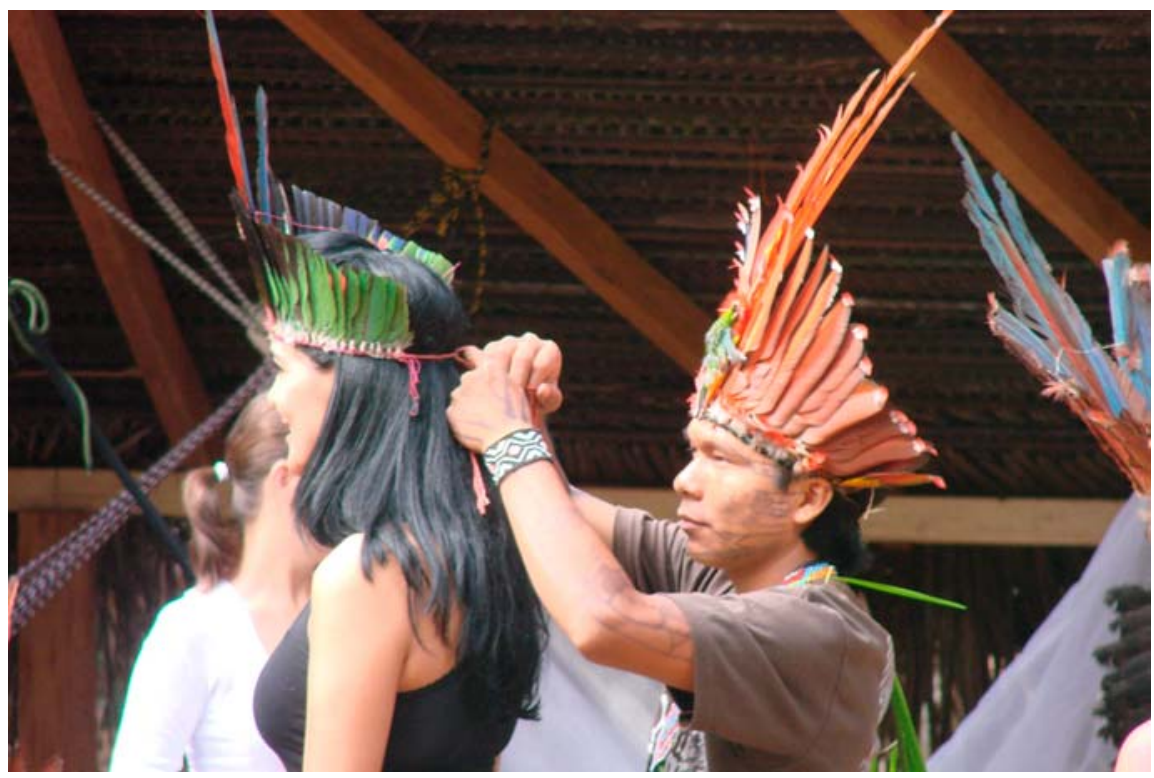

Figura 5. Fabiano Txana Bane presenteando Ilmara Cordeiro, que na época estava à frente da Secretaria Estadual de Turismo e Lazer (Setul) do Acre (foto da autora, 2010).

Se por ora nos detivemos em transformações decorrentes da aproximação dos Huni Kuin com relação às religiões ayahuasqueiras - como a prática de se "fardar na doutrina" - adentremos em movimento análogo e inverso, em que os nawa estão "se fardando na cultura huni kuin". Chegamos, pois, ao momento de mencionar que os nawa estão buscando fazer dietas dos Yawanawa e Huni Kuin, como modo de "conectar-se" com múltiplas "forças", fazendo das práticas indígenas um "caminho espiritual". No caso dos Huni Kuin, há uma constante demanda dos nawa de se "batizar" na "cultura huni kuin", através do nixpupima. "Trata-se de um "batizado" feito com "pimenta longa" (nixpu) que enegrece os dentes (que já devem ser definitivos), e que visa "endurecer o corpo" das crianças huni kuin. A partir daí, elas passam a assumir atividades específicas de gênero (Lagrou, 2007; Weber, 2006). Portanto, cada pessoa pode batizar-se apenas uma vez na vida. Durante o nixpu, a criança deve pular de modo a fortalecer seus ossos, por meio da agência das rezas chamadas pakadin (Weber, 2006). Esse ritual já foi bem descrito por outros pesquisadores, portanto nos convém deixar detalhadas descrições para outro momento e passar direto à questão: se é um ritual de ciclo da vida (Weber, 2006) 
destinado a preparar as crianças huni kuin para uma boa vida... que sentidos tem para os Huni Kuin batizar um nawa que já é adulto? Segundo os Huni Kuin, isso explica-se pelo fato de que não é aconselhável a pessoa andar nas matas, aldeias, roçados e rios, sem ser batizada: "para entrar na floresta" é preciso "ter nome". Após iniciarem o batismo dos nawa, um Huni Kuin explicou:

Mais velho mesmo já sou eu

então vou começar cantando

pedindo o lugar diferente que vocês chegaram

para vocês estarem aqui sentindo, nada estranho

tem que pedir a esse lugar que é onde vocês que anda, quando tá diferente, canta essa música

pedindo licença pra você tá ali

se não for isso, e entrar de qualquer jeito, de qualquer lugar, o espírito pega você!

Diarreia, vomita, pega você.

Se você é pessoa que está chegando, estranho.

Por isso tá protegendo a vida de vocês.

Portanto, se o katxanawa - "ritual da fertilidade" (Lagrou, 2007, p. 420-424) performatiza a invasão de estrangeiros, se tornando a forma preferencial de receber os nawa como convidados, podemos inferir que o nixpupima complementa essa incorporação do estrangeiro, através da produção do corpo e da pessoa ao modo huni kuin. Pois, como sabemos, as afecções da floresta podem ser perigosas. Assim, o nawa deve brincar no katxanawa ou entrar em uma roda de nixi pae, de preferência com um nome huni kuin, de modo a ser identificado perante os yuxin do lugar. Atendendo às diplomacias locais, o nawa evita maiores riscos diante desses outros "outros" da festa e da floresta. Não por acaso, o organizador nawa gosta de enfatizar que esse festival é diferente de outros, pois não teria tanto o caráter festivo, ${ }^{22}$ mas seu objetivo seria um "retiro" para

22 A mesma distinção fazem os Noke Koi (Katukina) quando diferenciam o festival (que corresponde à mesma festa que já faziam celebrando a demarcação da Terra Indígena Campinas, e seu principal intuito é brincar fazendo mariri) e o "Caminho de Cura", que é criado especialmente para visitantes nawa interessados em "cura". Ninawa Pai-da-Mata, liderança huni kuin $\rightarrow$ 
"trabalhar na espiritualidade", através da dieta que o nixpu "pede". ${ }^{23}$ Outro sentido recorrente entre os Huni Kuin nesse festival foi afirmar que após o nixpupima o nawa vai desenvolver com mais propriedade suas atividades e trabalhos. Sim, pois se o nixpu (pimenta) endurece o corpo das crianças, tornando-as ágeis e espertas, há de fazer o mesmo com os nawa.

\section{Caminhos de volta: da floresta para a cidade}

Chegamos, pois, aos caminhos de ida do nixi pae e uni em direção aos centros urbanos. São também cantos de volta (Carneiro da Cunha, 2009): a ida da bebida daime (para as aldeias) e sua volta como nixi pae. Para isso, investiguemos brevemente a categoria "medicina", que é central em distintos movimentos espirituais urbanos, especialmente os (neo)xamânicos. O uso em questão deriva-se da categoria pan-indígena utilizada pelos indígenas norte-americanos - medicine (Lanternari, 1974) - bastante utilizada para designar o peiote (Lophophora williamsii). Surge inicialmente como uma categoria de ida e volta nos Estados Unidos, quando os indígenas norte-americanos apropriam-se do termo não indígena, fazendo um movimento religioso e de resistência aos brancos, chamado "peiotismo" (Lanternari, 1974). A partir de então, a categoria faz um novo movimento de ida e volta, quando se espande pelo mundo através de xamanismos nas cidades. Novamente em um efeito looping a categoria "medicina" chega reverberando no Acre.

Seu uso faz clara alusão a uma terapêutica - em que a "cura" envolve intencionalidades de seres, "forças" e a circulação de "energias" - em oposição às premissas de uma medicina convencional (biomédica, alopática ou "ocidental") que parte de uma divisão corpo/mente/espírito. Também encontramos referência ao termo nos Andes, com o intuito de designar o conhecimento indígena local quanto às práticas terapêuticas, bem como em alguns contextos amazônicos do uso da ayahuasca. "Medicina" emerge, também, como categoria política em outros movimentos de "fortalecimento" da "medicina tradicional"

\footnotetext{
$\rightarrow$ da aldeia Novo Futuro, no mesmo sentido, chama atenção que seu festival é diferente, pois "é mais focado na ayahuasca mesmo, para cura mesmo".

23 Acerca das dietas nesse contexto em diálogo com nawa, ver Ferreira Oliveira (2016).
} 
indígena. Por sua vez, como parte dos processos de "valorização da cultura" no Acre, os Yawanawa, Huni Kuin e Noke Koi já utilizavam o termo em um movimento tradutório recente de evidenciar (e pesquisar) seus próprios sistemas de conhecimento em clara analogia à ciência e medicina ocidental. Portanto, "medicina" já era categoria objetificadora da "cultura" - assim como arte, culinária, histórias, festas, rituais - porém associada aos niipu rau (yawanawa) ou dau (huni kuin), traduzidos como "remédio" ou "veneno". Atualmente a categoria "medicina" é acionada em referência a vários agentes como: ayahuasca, coca, tabaco, Cannabis, etc. sendo que "medicinas da floresta" são aquelas utilizadas entre grupos indígenas do Acre, como rapé, sananga (Ferreira Oliveira, 2016) e kambô (Lima, 2005). Notamos, portanto, como se dá o efeito looping em torno da categoria "medicina" que passa de designação das "ervas medicinais", "remédios da mata" ou "folha", para se estender a uma concepção de "medicinas da floresta" incluindo esses outros agentes até então não considerados "medicinas".

Considerando que o deslocamento da fonte dos poderes é algo essencial no xamanismo (Taussig, 1987 apud Carneiro da Cunha, 2009), é pertinente fazer uma relação entre os deslocamentos desses pajés enquanto atores-rede (Latour, 2008) e seus fluxos e experiências com alteridades (humanas e não humanas) considerando o xamanismo como uma operação de tradução cósmica e cosmológica (Carneiro da Cunha, 2009). A análise de algumas categorias e expressões pode expressar essas traduções de mundos que operam em um processo de "equivocação controlada" (Viveiros de Castro, 2004). A "espiritualidade" é uma categoria central acionada enquanto estratégia comunicativa pelos indígenas nessas interações, que ocorrem por meio de aparentes consonâncias semânticas e de traduções que se dão pelos equívocos. Isso porque, apesar de estarem "usando os mesmos termos", não necessariamente indígenas e não indígenas estejam "falando da mesma coisa", uma vez que "traduzir é presumir que a equivocação sempre existe [...] é comunicar pelas diferenças, ao invés de silenciar o outro presumindo uma univocalidade" (Viveiros de Castro, 2004, p. 10-11, tradução minha).

O sentido comumente utilizado pelos não indígenas para o termo "espiritualidade" refere-se ao domínio de práticas e filosofias espirituais e é comumente utilizado no universo da Nova Era. Nesse contexto, "espiritualidade" está associada, por um lado, a valores e questões morais associadas ao "bem", 
considerados universais e contigentes a uma verdadeira essência humana, que mediante o processo de "civilização" teria passado por um processo de "desconexão" do "homem" e a "natureza". Nesse sentido, o contato com indígenas é visto como um dos modos de reestabelecer essa conexão. Por outro lado, o termo remete a uma não institucionalização das práticas espirituais e terapêuticas, levando a um dos sentidos no qual repousa a oposição entre religião e espiritualidade.

Já a forma como os Yawanawa referem-se à "espiritualidade" refere-se diretamente aos seres e forças presentes nas interações xamânicas. É ao que eles comumente se referem como "o mundo da espiritualidade yawanawa", que pode ser referida na língua yawanawa por yuxinhu (enquanto coletividades de "espíritos", forças, ou gentes outras). Para falar do "esquilo" em suas (geralmente maléficas) propriedades na reza, utiliza-se a palavra kapayuxinhu, ${ }^{24}$ onde kapa é "esquilo" e yuxinhu (traduzido por Nani Kate Yuve) é "a espiritualidade dele". Yuxin pode ser traduzido como espírito ou força vital (Lagrou, 2007; Yano, 2010) e $h u$ é o coletivizador. Se, quando falam de yuxin, yuve, vana, falam da "espiritualidade yawanawa", é porque a palavra "espírito" - enquanto um ser ou força invisível- não contempla a concepção yawanawa, assim como aquilo que evoca a "espiritualidade" (que não aponta para algo definido ou unificado, como a ideia de ente ou entidade, mas como uma potência, uma coletividade, com dinâmicas e cobranças específicas). Em suma, "ter espiritualidade" para os Yawanawa trata-se de ter poderes, alianças e domínio sobre os "espíritos" - o que pode querer dizer, dependendo do propósito, fazer o "mal" através de agressões xamânicas. Desse modo, contrasta com a noção de espiritualidade construída sob ideais da Nova Era, que preza a cura, e tem como valores centrais noções como amor, harmonia, equilíbrio, tranquilidade, desapego, generosidade, gratidão e leveza.

Podemos notar como a floresta, em sua acepção ameríndia (a grosso modo) - como espaço sociocósmico povoado de afecções e interações potencialmente perigosas - encontra consonâncias e dissonâncias em relação à floresta no imaginário contemporâneo ocidental, enquanto espaço encantado de transformações, "encontros consigo mesmo" e experiências benéficas na interação

24 Pérez Gil (1999) dispõe na íntegra uma versão desse shenipabu (história dos antigos). 
com os "seres da floresta". A "floresta" que move os nawa não é tanto aquela evocada pela ecologia ou ambientalismo (embora essa seja também acionada), mas é o lugar de uma transformação (pessoal, social, cósmica), advinda de uma "força espiritual" que lhe é própria e pode, nela, ser experienciada. A própria árvore da samaúma, conhecida por suas potencialidades perigosas, costuma ser associada apenas às suas propriedades curativas da "floresta".

Se, por um lado, a Jiboia é a Rainha da Floresta (Ferreira Oliveira, 2011) remetendo às suas feições daimistas -, podendo ser designada também como "mamãe jiboia" (Ferreira Oliveira, 2012), remetendo a um ser maternal que acolhe e ensina; por outro, a jiboia é também um ser constritor, capaz de produzir ataques espirituais. Entretanto, apesar de distintas ontologias em operação, em uma experiência multissensorial é possível que uma não exclua a outra, pois justamente o impacto experiencial com seres nos permite pensar em uma transição temporária entre universos ontológicos. Ambas podem estar operantes justamente pois é inerente aos yuxibu - nesse caso a jiboia (yube, "dona" do nixi pae) - a sua transformabilidade e encantamento em uma multiplicidade de formas. Vejamos com um exemplo: uma jovem de Curitiba, simultaneamente "andando" no "Caminho Vermelho" e "trabalhando" na "linha indígena" (das pajelanças huni kuin, yawanawa, etc.), expõe sua apreciação a respeito da visão do Mestre Irineu, dizendo que "ele mirou com a Virgem Maria. A Jiboia que se mostrou como Virgem Maria. Foi assim que ela apareceu. Por isso os daimistas miram com Virgem Maria, ela sabe que eles não aguentam ver ela em forma de cobra." Nestas apreciações, indicamos que as transformações dos yuxibu e dos yuxin variam de acordo com as intencionalidades dessas forças, que também se manifestam a partir da perspectiva de quem vê.

Poderíamos ainda analisar as pluralidades ontológicas envolvidas na tradução da expressão haux dos Huni Kuin. Conversando com alguns Huni Kuin, eles contam que os especialistas xamânicos utilizam o haux para abrir rituais ou, durante eles, em momentos de muita força (pae) (sendo que para dispersar energias ruins consideradas "pesadas" é apropriado usar expressão xó!). É também notória sua utilização no encerramento de rituais, seja em um ritual de nixi pae ou como forma de firmar o que foi rezado durante um trabalho. Porém, tal expressão passou a ser usada de formas diversas nos circuitos urbanos e nos próprios rituais. Exemplo curioso foi ter assistido a um vídeo de receitas veganas que foi finalizado com "haux haux!". Desse modo, um modo expressivo 
próprio do campo do xamanismo passa agir em tantos outros campos semânticos. Isso porque "haux haux haux" virou uma espécie de saudação, seja para iniciar algo, para reforçá-lo ou, principalmente, finalizar uma fala. Hoje, tal expressão circula ao lado de algumas outras, como o ihu dos Yawanawa, o aho dos coletivos xamânicos urbanos conhecidos como Caminho Vermelho, o viva! dos daimistas ou o namastê dos iogues. O haux segue, assim, como uma expressão dotada de poder, que "energiza" as interações. Haux é uma espécie de potência sonora evocativa. Assim, se escutam afirmações como "muito haux!", ao se desejar algo para alguém (em um sentido, talvez, próximo de se desejar "muito axé"). Como disse recentemente uma liderança de um grupo espiritual urbano: "Namastê aho haux haux!"

Diante de todas essas expressões, observo que, atualmente, o haux é aquela que tem sido adotada mais amplamente pelos coletivos urbanos (mas também pelos Yawanawa, Katukina, dentre outros) contrastando com uma predominância anterior da expressão aho. ${ }^{25} \mathrm{Ou}$ seja, em termos de performatividade de expressões e evocação de forças, a montanha (enquanto universo ontológico do Caminho Vermelho) vem cedendo espaço à floresta. O haux tem viajado pela rede do cipó, atravessando fronteiras. Quando estive em um ritual de ayahuasca na Colômbia, na região de Medellín, dirigido por um indígena uitoto para um grupo de não indígenas, na abertura do ritual surpreendi-me ao ver que sua saudação inicial foi "haux!", ao que prontamente várias pessoas responderam "haux haux haux!". Ainda, certa vez, em 2011, perguntei a Gildo Sales Kaxinawá, de passagem por Florianópolis, sobre tal expressão. Ao que ele me respondeu: "Eu uso mais quando viajo!" Anos depois, quando novamente o interroguei sobre o assunto, ele me explicou que "haux é como aho dos Guarani", ${ }^{26}$ em referência a essa expressão utilizada transnacionalmente por diversos grupos xamânicos urbanos. Ou seja, certos usos de categorias nativas emergem claramente das associações com os nawa, gerando, por sua vez, novas associações, como a que passou a ser feita por este Huni Kuin. Portanto, não se trata de polarizar

25 Para uma análise dessa expressão ritual à luz de questões estéticas ver Ferreira Oliveira (2009).

26 Ele referia-se a uma aldeia Guarani em Biguaçu (SC), onde assistiu aos Guarani utilizarem a expressão aho, proveniente de aho metakyue oyasin (por sua vez apropriada dos Lakota via Caminho Vermelho) traduzido como "por todas as nossas relações" ou "somos todos aparentados", que passou a operar em consonância com a expressão guarani aguyjevete (Ferreira Oliveira, 2009; Rose, 2010). 
as associações ou fixar sentidos (quanto a espiritualidade ou do haux) entre indígenas e não indígenas, uma vez que os sujeitos passam a dialogar por meio dos mesmos termos com novos sentidos, podendo captar as traduções que estão em jogo e operar através delas.

\section{Pajelança como celebração}

Para concluir, cabe-nos fazer algumas inferências sobre os rituais de uni e nixi pae que ocorrem nas aldeias e nos centros urbanos, e como podemos pensá-los através do eixo festa e xamanismo. Como Carid Naveira (1999) argumenta, os próprios Yawanawa estabelecem essa polaridade: associando a festa ao público, à comensalidade, a brincadeira com os afins, e o xamanismo como privado e envolto de dietas e restrições interativas. Conforme Carid Naveira (1999) e Pérez Gil (1999), entre os Yawanawa há dois modos de uso do uni: o uso do shointia durante os trabalhos de reza, e o uso do uni durante os mariri para animar a festa. É necessário distinguir que enquanto o mãmã - "caiçuma forte" feita de mandioca fermentada - era tomado por todos os adultos (incluindo mulheres), o uso do uni no mariri era restrito aos homens iniciados no xamanismo. Portanto a "roda de uni" é uma invenção recente, enquanto um modo interativo onde grande parte da aldeia participa.

O que argumentamos aqui é que a polaridade entre festa e xamanismo destacada por Carid Naveira (1999) em relação à cosmologia yawanawa não se aplica plenamente à ação ritual nos meios urbanos, onde há uma coexistência dessas dimensões. Ainda que certamente o uso do chá em um trabalho de reza com uni ou nixi pae é muito distinto do tipo de interação mais festiva que pode ocorrer nas rodas de uni ou nixi pae. Dependendo do tipo de evento, a pajelança deve ser minimizada, e no mariri podem todos participar. Presume-se, portanto, que essas novas relações produzem uma modalidade de interação atravessada pela festa, onde a pajelança é, além de terapêutica de cura e agressão, uma celebração, animada aos atabaques e violão.

Consideramos não apenas a tradução de categorias, mas das próprias práticas que adquirem novas formas e significados, gerando novos fenômenos. Originalmente, nessas festividades, a bebida central era a "caiçuma forte" (mãmã) feita de macaxeira fermentada para causar embriaguez. Observando 
atualmente os festivais considerados, vemos que a caiçuma assumiu um lugar periférico nessas ocasiões. Entretanto, durante os festivais, a ayahuasca é tomada ininterruptamente - de dia em grupos dispersos e ações individuais e, de noite, como parte da programação do evento nas sessões do nixi pae. A caiçuma, ao invés de ser o centro ${ }^{27}$ motriz da festa, tornou-se - quando presente - um "item de atração" na programação dos festivais, como no caso do Festival Yawa.

A embriaguez (pae) da caiçuma cedeu espaço à força (pae) da ayahuasca. Frente à crescente valorização da ayahuasca, estaríamos diante de uma espécie de "ayahuasquização do mariri", ou mesmo de uma "ayahuasquização do xamanismo pano"? ${ }^{28}$ A própria ayahuasca, agora no centro da prática xamânica - o que podemos relacionar ao uso não indígena religioso da bebidavem "puxando" outras "medicinas" através das dietas, inclusive com os nawa. Não podemos deixar de mencionar que a própria caiçuma, devido a seu poder de "dar porre" e gerar efervescência e exaltação em meio às brincadeiras, foi coibida pelos missionários em tempos passados. Por outro lado, o ânimo festivo adentra o ritual de nixi pae, através da "dança da jiboia" (munu), considerada pelos Huni Kuin como advinda do nixi pae: uma fila vai serpenteando pelo terreiro movimentando (a jiboia) e os demais participantes. Em movimento semelhante, formações próprias de "festa de mariri" podem surgir em meio à roda de uni. A mais frequente delas é meshtiakea - "feito roda", meshti (roda), akea (feito) - que foi inserida logo no início do ritual. Depois de tomar o uni, em alguns rituais, formam um círculo a partir dos braços dados, e vão girando lentamente à medida que a força (pae) vai chegando. Notamos assim a inserção de elementos do mariri nas sessões de cipó, e vice-versa. Haveria, portanto, uma dinâmica inversa, análoga e complementar entre processos que podemos chamar de "marirização da ayahuasca" - nos quais elementos do mariri adentram rituais de ayahuasca - e de "ayahuasquização do mariri", onde festas que tradicionalmente ocorriam com caiçuma estão sendo praticadas com ayahuasca.

27 Uma exceção ao caso é o Festival Atsá - justamente referenciado como "festa da mandioca" - iniciado em 2015, que ocorre na aldeia dos Puyanawa em Mâncio Lima (AC).

28 Segundo Pérez Gil (1999) a caiçuma é vista como algo de cariú (branco). 


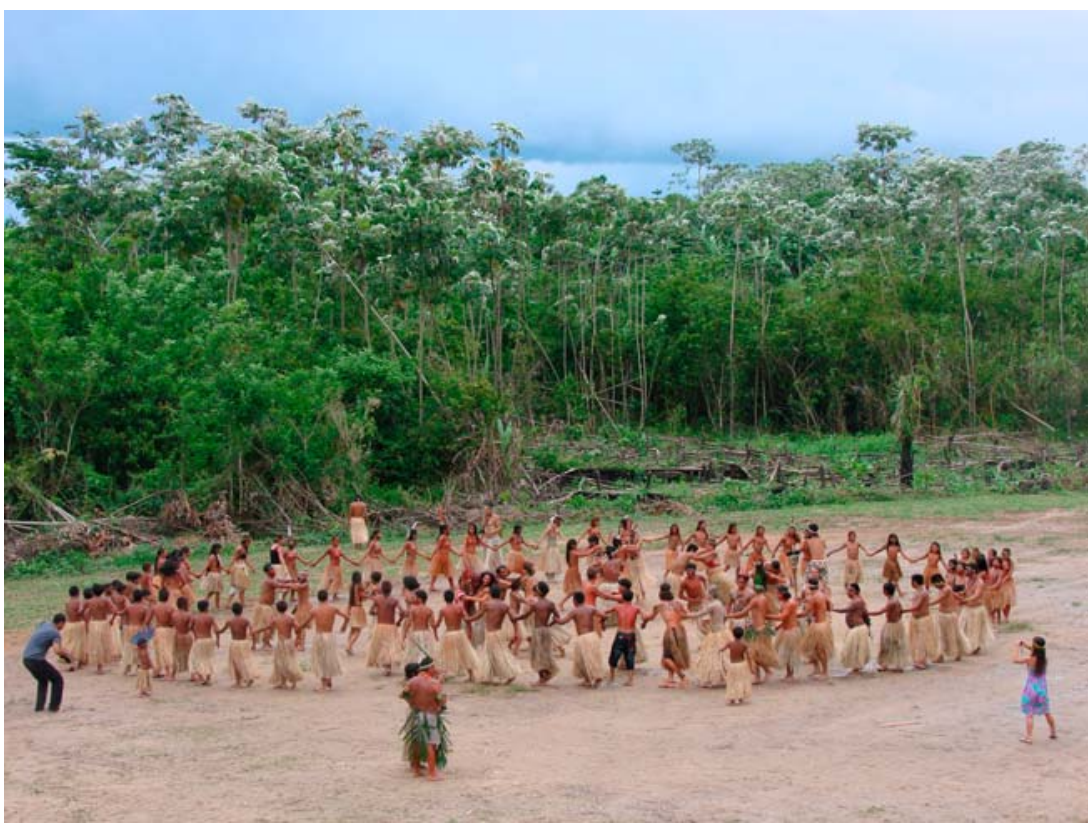

Figura 6. Brincadeira "Rorainonode" no Festival Yawa (foto da autora, 2011).

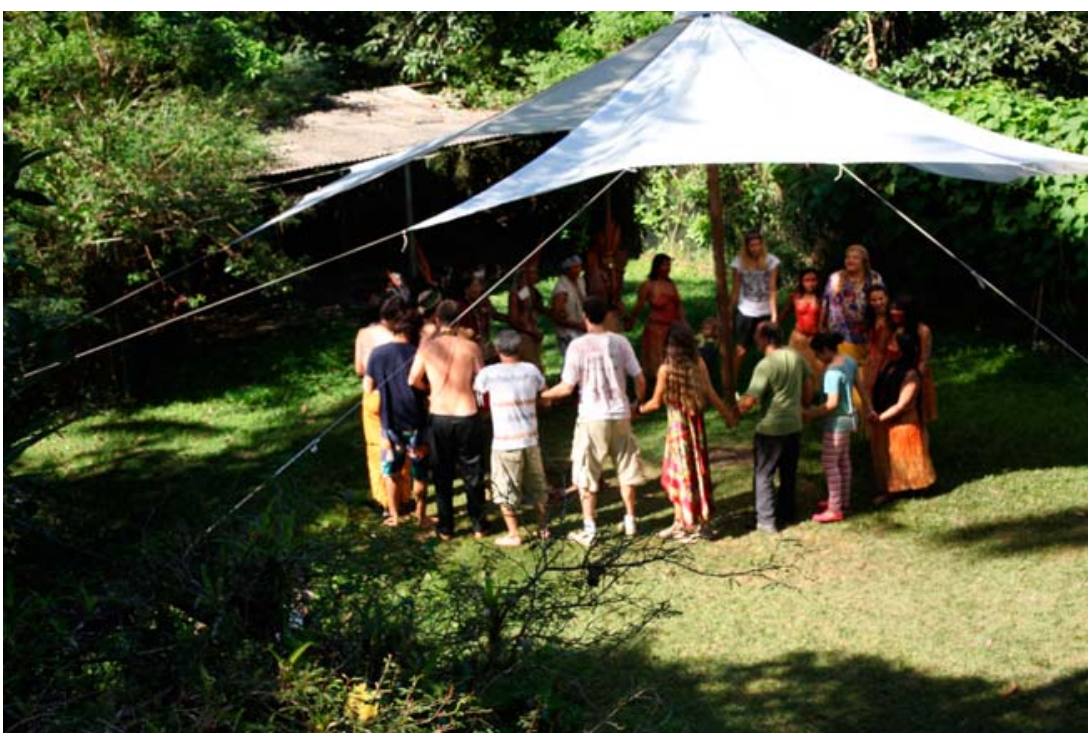

Figura 7. Roda de mariri durante "Mini Festival" na Rio+20 (foto da autora, 2012). 
Ainda, as práticas festivas têm também o poder de permear outros rituais, adentrando os terrenos do xamanismo. Assim ocorreu na Dança das Estrelas na comunidade do Santo Daime em Florianópolis, no ano de 2013. Essa "cerimônia" é inspirada na ideia de "Dança dos Espíritos" a partir da "Ghost Dance" dos indígenas norte-americanos, e no Fogo Sagrado ocorre anualmente, durante quatro noites de dança tomando variadas "medicinas" (sendo que de dia os "dançantes" descansam, e fazem abstinência sexual durante todo o ritual). Naquela ocasião, os "padrinhos" da igreja recebiam uma visita especial. Era Txana Ikakuru, um jovem huni kuin do Jordão que reside na aldeia Boa Vista e é considerado "especialista" em cantos de cipó, de festa e nas brincadeiras e improvisações próprias do katxanawa. Dentro do salão é feita uma fogueira e em volta, em amplo círculo, dançam os participantes enfeitados e segurando seus bastões.

Durante as quatro noites, em alguns momentos Txana Ikakuru introduziu fragmentos do katxanawa e conduziu a dança. Reunidos na casa dos "padrinhos" anfitriões, estavam também as lideranças do Fogo Sagrado, o jovem Ikakuru e um membro do grupo Shaku Bena, que combinaram esse arranjo previamente ao início da "cerimônia". Desse modo, o katxanawa "chamando a força dos legumes" juntou-se à ação ritual da Dança das Estrelas que precisamente opera por "oferendas" de alimentos aos "ancestrais". Contingencialmente a Dança das Estrelas incorporou o katxanawa. Do mesmo, foi selecionado o primeiro verso do katxanawa chamado "sheki (milho) hawã (muito) huini (chegou)". O milho, por sua vez, é central na ritualística do Fogo Sagrado, e durante a dança é lançado ao fogo, alternadamente com frutas e generosos punhados de tabaco como forma de "levantar" os "rezos" de pedidos e agradecimentos ao Grande Espírito. Notamos, pois, como se deu a conjunção de dois gêneros performáticos, em um mesmo evento: em torno de um fundo semântico que aciona elementos similares, ajustando-se um ao outro na ação ritual.

Há algumas interações típicas de mariri nas rodas de uni atualmente, mesmo nas aldeias. Porém, quando o uni se desloca para a cidade, elementos outros do mariri - como as danças e brincadeiras - podem aparecer quando se quer "apresentar a cultura". Dessa forma, visualizamos uma conexão entre esse modo de atuar do mariri - em que cantos, versos, danças, podem deslocar-se, alocando-se em outros modos expressivos (palestras, apresentações oficiais, rituais de cipó) - com a performatividade da "cultura". Como destaca Lagrou (2007), 
um katxanawa pode ser feito também antes de uma festa do nixpupima. Weber (2006) descreve como o katxanawa era feito em meio às atividades da escola entre os Huni Kuin no rio Humaitá.

Quanto à dualidade festa e xamanismo (ainda que tenha se tornado de fronteiras porosas em alguns usos contemporâneos do cipó) podemos notar que há um modo de ação ritual que justamente reifica essa separação: o início é guiado pelos cantos dos anfitriões da cerimônia, que depois (quando já "baixou a força" do chá) "é aberta" para o uso de instrumentos (principalmente violão) e para os demais participantes cantarem, tornando-se mais festiva. Ou seja, essa oposição, ainda que aparentemente diluída, ela segue repetindo-se em fractais e escalas. Outra delas seria justamente quanto à combinação entre brincadeiras festivas de dia e rituais xamânicos de noite, típica dos festivais.

A partir dos Wajãpi das Guianas, Sztutman (2003, p. 29) aborda as festas de caxiri e sessões xamânicas enquanto duas modalidades de comunicação ritual: uma propiciada pela embriaguez das festas com bebida fermentada - onde beber caxiri revela-se modelo decisivo de socialidade (Sztutman, 2003, p. 30) - e outra pelas viagens xamânicas. Argumentando no mesmo sentido de Carid Naveira (1999) e outras etnografias sobre povos ameríndios, o autor expõe que, por um lado, observamos nas sessões xamânicas uma atuação no domínio que pode se qualificar como privado (Sztutman, 2003, p. 32), limitado e de viagens individuais (Sztutman, 2003, p. 34), por outro, nas festas de caxiri, de um caráter eminentemente público (Sztutman, 2003, p. 32) e coletivo (Sztutman, 2003, p. 34), no qual a comunicação é de instância exagerada, com embriaguez e explosão de euforia. Quanto às Guianas, Sztutman afirma que se a oposição entre festa de caxiri e sessões xamânicas não se verifica em toda parte, é porque há um deslocamento fundamental dos termos mas não das relações em jogo (Sztutman, 2003, p. 37). O deslocamento dos pajés karipuna (Tassinari, 1998 apud Sztutman, 2003, p. 39) em relação aos Wajãpi é notável: ele assume um lugar de caráter eminentemente público, pois toma a direção do ritual coletivo e faz sua faculdade curativa um dom aberto e facilmente reconhecível (Sztutman, 2003, p. 39).

A imagem do xamã karipuna que fala em nome da comunidade em um ritual coletivo (Tassinari, 1998 apud Sztutman, 2003) pode ser reencontrada entre os Piaroa (Overing, 1975 apud Sztutman, 2003, p. 40) onde o xamã, 
ora mago, ora "homem de pensamentos", agrega, além da função de cura e agressão, o papel de líder político e chefe cerimonial (atributos que se devem ao acúmulo de conhecimentos obtidos por sua capacidade de transitar). A partir desse fundamento, encerramos com o ponto de partida acerca da dualidade entre festa e xamanismo, lançando a questão: esse atual deslocamento do pajé para o domínio público no Acre - o que pode bem ser sinalizado no uso do terreiro e do "chapéu de palha" (shuhu yawanawa e shubuã huni kuin) para uso do cipó - levaria a uma reconfiguração desses dois modos de liderança? Ou seja, que conexões podemos encontrar entre as famosas "falas de chefe" e a solenidade cerimonial da Nova Era, onde o pajé tem que falar a um público no início do ritual "apresentando a cultura" e agradecendo todos os presentes? É bem possível que a interação entre essas instâncias comunicativas esteja gerando uma nova configuração em que liderança política e xamânica são conjugadas em uma mesma pessoa, justamente devido a que ao pajé se pede ter habilidades performáticas que mais bem usualmente são atribuídas ao chefe cerimonial.

Em suma, observamos como o cipó é um importante mediador nesse novo modo dos indígenas em lidar com as alteridades. A cidade, por sua vez, também evoca a festa: como modo de suavização do xamanismo, por conseguinte, como produção de uma generalização do uso da ayahuasca, a pajelança assume um caráter festivo em que todos podem participar (operando, portanto, a um modo não indígena de uso do chá). A ayahuasca mostra-se como um mediadora (Calavia Sáez, 2014) de xamanismos e festas: é atravessadora (Calavia Sáez, 2014) e passadora de fronteiras (Losonczy; Mesturini, 2010), levando a festa para o cipó, e o cipó para o centro da festa.

\section{Referências}

CAICEDO FERNANDEZ, A. Neochamanismo y modernidad. Lecturas sobre la emancipación. Nómadas, Bogotá, n. 26, p. 114-127, 2007.

CALAVIA SÁEZ, O. Teorías, actores y redes de la ayahuasca. Ilha, Florianópolis, v. 16, n. 1, p. 7-40, 2014.

CALAVIA SÁEZ, O.; ARISI, B. La extraña visita: por una teoría de los rituales amazónicos. Revista Española de Antropología Americana, v. 43, n. 1, p. 205-222, 2013. 
CARID NAVEIRA, M. Yawanawa: da guerra à festa. 1999. Dissertação (Mestrado em Antropologia Social)-Centro de Filosofia e Ciências Humanas, Universidade Federal de Santa Catarina, Florianópolis, 1999.

CARNEIRO DA CUNHA, M. Xamanismo e tradução. In: CARNEIRO DA CUNHA, M. Cultura com aspas: e outros ensaios. São Paulo: Cosac Naify, 2009.

CHAUMEIL, J.-P. Ideología turística en Amazonía. Ensayo sobre una nueva religión. In: VALCUENDE DEL RÍO, J. M. (Coord.). Amazonía: viajeros, turistas y poblaciones indígenas. El Sauzal: ACA: Pasos, 2012. p. 157-172.

COUTINHO, T. C. Xamanismo da floresta na cidade: um estudo de caso. 2011. Tese (Doutorado em Sociologia e Antropologia)-Instituto de Filosofia e Ciências Sociais, Universidade Federal do Rio de Janeiro, Rio de Janeiro, 2011.

FERREIRA OLIVEIRA, A. No caminho, em busca da visão: narrativas e performances rituais no Fogo Sagrado. 2009. Trabalho de Conclusão de Curso (Graduação em Ciências Sociais)-Centro de Filosofia e Ciências Humanas, Universidade Federal de Santa Catarina, Florianópolis, 2009.

FERREIRA OLIVEIRA, A. Dai-me nixi pae, uni medicina: alianças e pajés nas cidades. In: REUNIÃO DE ANTROPOLOGIA DO MERCOSUL, 10., 2011, Curitiba. Anais... Curitiba: Universidade Federal do Paraná, 2011.

FERREIRA OLIVEIRA, A. Yawa-nawa: alianças e pajés nas cidades. 2012. Dissertação (Mestrado em Antropologia Social)-Centro de Filosofia e Ciências Humanas, Universidade Federal de Santa Catarina, Florianópolis, 2012.

FERREIRA OLIVEIRA, A. Plantas, dietas, éticas yawanawa: iniciações xamânicas contemporâneas. In: REUNIÃO BRASILEIRA DE ANTROPOLOGIA, 30., 2016, João Pessoa. Anais... João Pessoa: Universidade Federal do Rio Grande do Norte, 2016.

LABATE, B.; COUTINHO, T. O meu avô deu a ayahuasca para o Mestre Irineu: reflexões sobre a entrada dos índios no circuito urbano de consumo de ayahuasca no Brasil. Revista de Antropologia, São Paulo, v. 57, n. 2, p. 215-250, 2014.

LAGROU, E. Uma etnografia da cultura kaxinawá: entre a cobra e o inca. 1991. Dissertação (Mestrado em Antropologia Social)-Centro de Filosofia e Ciências Humanas, Universidade Federal de Santa Catarina, Florianópolis, 1991.

LAGROU, E. Huni Kuin (Kaxinawá). Povos Indígenas no Brasil. nov. 2004. Disponível em: <https://pib.socioambiental.org/pt/Povo:Huni_Kuin_(Kaxinaw\%C3\%A1)>. Acesso em: 30 maio 2017.

LAGROU, E. A fluidez da forma: arte, alteridade e agência em uma sociedade amazônica (Kaxinawa, Acre). Rio de Janeiro: Topbooks, 2007. 
LANTERNARI, V. As religiões dos oprimidos. São Paulo: Perspectiva, 1974.

LATOUR, B. Reensamblar lo social: una introducción a la teoría del actor-red. Buenos Aires: Manantial, 2008.

LIMA, E. C. de. Kampu, kampo, kambô: o uso do sapo-verde entre os Katukina. Revista do Patrimônio Histórico e Artístico Nacional, Rio de Janeiro, n. 32, p. 254-267, 2005.

LIMA, E. C. de; LABATE, B. "Remédio da ciência" e "remédio da alma": os usos da secreção do kambô (Phyllomedusa bicolor) nas cidades. Campos, Curitiba, v. 8, n. 1, p. 71-90, 2007.

LOSONCZY, A.-M.; MESTURINI, S. La selva viajera: rutas del chamanismo ayahuasquero entre Europa y América. Religião e Sociedade, Rio de Janeiro, v. 30, n. 2, p. 164$183,2010$.

MAGNANI, J. G. C. O xamanismo urbano e a religiosidade contemporânea. Religião e Sociedade, Rio de Janeiro, v. 20, n. 2, p. 113-140, 2000.

PÉREZ GIL, L. Pelos caminhos de Yuve: cura, poder e conhecimento no xamanismo yawanawá. 1999. Dissertação (Mestrado em Antropologia Social)-Centro de Filosofia e Ciências Humanas, Universidade Federal de Santa Catarina, Florianópolis, 1999.

PERRONE-MOISÉS, B. Festa e guerra. 2015. Tese (Livre Docência)-Faculdade de Filosofia, Letras e Ciências Humanas, Universidade de São Paulo, São Paulo, 2015.

ROSE, I. S. de. Tata endy rekoe - fogo sagrado: encontros entre os Guarani, a ayahuasca e o Caminho Vermelho. 2010. Tese (Doutorado em Antropologia Social)-Centro de Filosofia e Ciências Humanas, Universidade Federal de Santa Catarina, Florianópolis, 2010.

SZTUTMAN, R. Comunicações alteradas: festa e xamanismo na Guiana. Campos, v. 4, p. 29-51, 2003.

VIVEIROS DE CASTRO, E. Perspectival anthropology and the method of controlled equivocation. Tipití, San Antonio, v. 2, n. 1, p. 3-22, 2004.

WEBER, I. Um copo de cultura: os Huni Kuin (Kaxinawá) do rio Humaitá e a escola. Rio Branco: Edufac, 2006.

YANO, A. A fisiologia do pensar: corpo e saber entre os Caxinauá. 2010. Dissertação (Mestrado em Antropologia Social)-Faculdade de Filosofia, Letras e Ciências Humanas, Universidade de São Paulo, São Paulo, 2010.

Recebido: 31/05/2017 Aceito: 14/03/2018 | Received:5/31/2017 Accepted: 3/14/2018 